\title{
MOTIVASI BELAJAR DI SAAT PANDEMI COVID-19 BAGI SISWA MADRASAH ALIYAH ALMISRI, DI DESA CURAHMALANG, KECAMATAN RAMBIPUJI- JEMBER
}

\author{
Nely Supeni \\ Sekolah Tinggi Ilmu Ekonomi Mandala \\ Email: nely@stie-mandala.ac.id
}

\begin{abstract}
ABSTRAK
Kegiatan Pengabdian Kepada Masyarakat kali ini dilakukan di Madrasah Aliyah (MA) Almisri Desa Curahmalang, Kecamatan Rambipuji, Kabupaten Jember. Tujuan pelaksanaan kegiatan ini adalah: 1) Untuk memotivasi para siswa kelas 12 MA Almisri agar tetap menyelesaikan pendidikan hingga lulus walaupun di tengah pandemi covid-19 dan 2) Untuk memotivasi para siswa kelas 12 MA Almisri agar setelah lulus dapat melanjutkan pendidikan ke jenjang yang lebih tinggi yaitu melanjutkan studi ke bangku kuliah. Metode pelaksanaan kegiatan yaitu dengan melakukan kunjungan ke MA Almisri, bertatap muka dengan siswa kelas 12 dengan tetap mematuhi protokol kesehatan. Hasil dari pelaksanaan kegiatan yaitu para siswa semakin termotivasi untuk menyelesaikan sekolah hingga lulus dan tidak sedikit dari mereka yang antusias untuk melanjutkan studi lanjut ke bangku kuliah, hal ini dapat dilihat dari respon yang mereka berikan, dengan meminta contact person dan juga nomer telpon STIE Mandala.
\end{abstract}

Kata Kunci: Pengabdian Kepada Masyarakat, Siswa, Motivasi

\section{ABSTRACT}

This Community Service Activities at Madrasah Aliyah (MA) Almisri, Curahmalang Village, Rambipuji District, Jember Regency. The objectives of the implementation of this activity are: 1) To motivate the 12th grade students of MA Almisri to continue completing education until graduation even in the midst of the Covid-19 pandemic and 2) To motivate the 12th grade students of MA Almisri so that after graduating they can continue their education to a more advanced level. high, namely continuing studies to college. The method of implementing the activity is by making a visit to MA Almisri, meeting face to face with grade 12 students while adhering to health protocols. The results of the implementation of the activity were that students were increasingly motivated to finish school until graduation and not a few of them were enthusiastic about continuing their studies at college, this can be seen from the responses they gave, by asking for a contact person and also STIE Mandala's telephone number.

Keywords: Community Service, Students, Motivation

\section{BAB 1. PENDAHULUAN}

\subsection{Analisis Situasi}

Desa Curahmalang tidak terlepas dari sejarah para perantau yang 
terdiri dari tiga suku bangsa utama yang ada di P. Jawa, yakni suku Jawa, Madura dan Sunda. Dari ketiga suku ini melahirkan komunitas masyarakat desa Curahmalang yang heterogen. Sehingga bukan hal baru jika masyarakat desa Curahmalang bisa berbahasa dari ketiga suku diatas. Namun perbedaan ini tidak membuat salah satu suku mendiskriminasikan suku yang lainnya, justru perbedaan-perbedaan yang ada di masyarakat ini menjadikan warga desa Curahmalang memiliki beberapa budaya yang sangat menarik. Hal ini dapat dilihat pada saat adanya kegiatan didesa, semua suku yang ada di desa Curahmalang ikut berpartisipasi bahkan mereka dapat berkolaborasi dalam suatu kegiatan desa tanpa merasa salah satu suku lebih unggul dari yang lainnya.

Nama "Curahmalang" ternyata ada filosofinya, nama tersebut diambil berdasarkan adanya dua sungai yang saling melintang satu dengan yang lainnya. Dua sungai tersebut berada tepat disebelah utara masjid di Dusun Gumawang. Kedua sungai ini termasuk sungai yang uniqe, karena posisinya yang melintang antara satu dengan yang lainnya, sehingga hal inilah yang menjadi filosofi munculnya nama "Curahmalang".

Desa Curahmalang terdiri dari 4 dusun, diantaranya: 1) Dusun Krajan, 2) Dusun Gereng, 3) Dusun Gumawang dan 4) Dusun Gumuksari. Dari keempat dusun ini masing-masing memiliki potensi yang dapat dikembangkan, misalnya di dusun Gumawang yang terdapat Usaha Mikro Kecil dan Menengah (UMKM) pembuatan tahu, pembuatan batu bata, dan hidroponik. Kemudian di dusun Krajan juga terdapat UMKM pembuatan tas. Dari masing-masing UMKM yang ada tersebut telah menunjukkan bahwa masyarakat desa Curahmalang adalah masyarakat yang produktif, memiliki kreatifitas untuk mengembangkan usaha dan mandiri. Beberapa hal diatas adalah sebagian potensi yang dapat di gali dari desa Curahmalang.

Selain beberapa potensi yang sudah dijelaskan diatas, terdapat potensi lain yang cukup menarik di dusun Gumuksari yang sekaligus bisa dijadikan lokasi Pengabdian Kepada Masyarakat, di dusun Gumuksari terdapat Madrasah Aliyah yang bernama Madrasah Aliyah Almisri. Madrasah tersebut 
sebagai pengembangan dari lembaga pendidikan yang sebelumnya hanya menyediakan pendidikan jenjang Madrasah Ibtidaiyah (MI) setingkat Sekolah Dasar (SD) dan Madrasah Tsanawiyah (MTs) setingkat Sekolah Menengah Pertama (SMP). Pada saat Lembaga Pendidikan ini hanya menyediakan sampai jenjang MI, masyarakat di dusun Gumuksari sebagian besar hanya lulusan MI saja. Setelah mereka lulus dari MI, mereka langsung bekerja di sawah membantu orang tua dan kemudian menikah. Begitupun pada saat Lembaga Pendidikan ini meningkatkan jenjang pendidikannya sampai pada MTs, sebagian besar masyarakatnya juga sekolah sampai MTs, setelah siswa lulus mereka bekerja disawah membantu orang tua dan kemudian menikah. Terus dan terus seperti itu. Perihal diatas menjadi pertimbangan pihak Pengelola Lembaga Pendidikan untuk menfasilitasi jenjang pendididikan yang lebih tingi yaitu dengan mendirikan Madrasah Aliyah yang setingkat dengan Sekolah Menengah Atas (SMA) agar masyarakat dapat memiliki pendidikan yang lebih tinggi lagi.

Berdasarkan latar belakang diatas maka kami selaku Dosen STIE Mandala melakukan kegiatan Pengabdian Kepada Masyarakat khususnya di MA Almisri dengan tujuan sebagai berikut:

1. Untuk memotivasi para siswa kelas $12 \mathrm{MA}$ Almisri agar tetap menyelesaikan pendidikan hingga lulus walaupun di tengah pandemi covid-19.

2. Untuk memotivasi para siswa kelas $12 \mathrm{MA}$ Almisri agar setelah lulus dapat melanjutkan pendidikan ke jenjang yang lebih tinggi yaitu melanjutkan studi ke bangku kuliah.

\subsection{Permasalahan Mitra}

Madrasah Aliyah Almisri yang berada di Desa Curahmalang, Kec Rambipuji Jember merupakan suatu jenjang pendidikan paling tinggi di yayasan Almisri. Jenjang ini sebagai pengembangan pendidikan dari beberapa jenjang pendidikan yang ada sebelumnya yaitu Madrasah Ibtidaiyah (MI) dan Madrasah Tsanawiyah (MTs). Peningkatan jenjang ini berdasarkan pertimbangan pihak sekolah yang berupaya untuk menfasilitasi warga di desa Curahmalang untuk bisa 
memperoleh pendidikan yang setara dengan Sekolah Menengah Atas (SMA), mengingat masyarakat di desa Curahmalang yang sebenarnya giat untuk menuntut ilmu namun seringkali menjadikan jarak tempuh dari rumah ke sekolah menjadi hal yang dipertimbangkan untuk melanjutkan sekolah ke jenjang yang lebih tinggi. Permasalah ini yang menjadikan Kepala Sekolah berupaya menfasilitasi masyarakat untuk melanjutkan sekolah ke tingkat yang lebih tinggi dengan membuka Madrasah Aliyah Almisri di dusun Gumuksari, agar masyarakat dapat melanjutkan jenjang pendidikan yang lebih tinggi dari MTs.

Mengingat sebagian besar siswa MA Almisri adalah masyarakat desa Curahmalang sendiri, sehingga perlu adanya suatu motivasi kepada siswa untuk tetap semangat menyelesaikan sekolah di Madrasah Aliyah Almisri sampai lulus walaupun di tengah pandemi covid-19. Motivasi ini dapat membuka wawasan siswa bahwasannya mengenyam pendidikaan yang lebih tinggi dari MTs memiliki peran penting untuk memajukan desa Curahmalang kedepannya. Pelaksanaan kegiatan pengabdian kepada masyarakat ini tidak hanya sebatas itu saja, namun kami juga memberikan wawasan kepada siswa agar termotivasi melanjutkan studi lanjut ke bangku kuliah.

\section{BAB 2. SOLUSI DAN TARGET}

\subsection{Solusi}

Berdasarkan permasalah mitra yang telah dibahas di bab sebelumnya, maka solusi yang dapat dilakukan untuk mengatasi permasalahan tersebut adalah memotivasi para siswa Madrasah Aliyah Almisri agar tetap semangat melanjutkan sekolah di tengah Pandemi covid-19, dan membuka wawasan pada para siswa agar termotivasi melanjutkan pendidikan ke jenjang yang lebih tinggi yaitu kuliah di Perguruan Tinggi.

Memotivasi para siswa kelas 12 MA Almisri kami lakukan dengan bertatap muka di dalam kelas. Hal ini sudah seizin pihak sekolah, mengingat sekarang sudah memasuki era new normal, dan yang penting kegiatan ini dilaksanakan dengan tetap mematuhi protokol kesehatan yaitu menggunakan masker dan menjaga jarak dengan para siswa. 
Motivasi yang kami lakukan ternyata disambut antusias oleh para siswa, selain mereka sudah lama stay at home dan sudah merindukan bangku kelasnya, kedatangan kami ternyata memang ditunggu karena para siswa senang sekali apabila ada pihak external yang berkunjung disekolah mereka. Sehingga pada akhirnya banyak siswa yang memberikan feedback atas motivasi yang kami berikan, bahkan beberapa diantara mereka ada yang langsung merespon meminta nomer telpon STIE Mandala karena mereka ingin setelah lulus dari MA Almisri akan melanjutkan kuliah di STIE Mandala.

\subsection{Target}

Target kegiatan pengabdian kepada masyarakat ini yaitu bagaimana siswa kelas 12 Madrasah Aliyah Almisri desa Curahmalang, Kec Rambipuji - Jember ini masih memiliki semangat untuk belajar dan menyelesaikan pendidikannya di MA Almisri dengan maksimal. Kemudian kegiatan ini juga memberikan informasi dan membuka wacana kepada siswa 12 MA Almisri agar setelah lulus dari MA Almisri mereka bisa melanjutkan pendidikan ke jenjang yang lebih tinggi yaitu kuliah khususnya dapat kuliah di STIE Mandala.

\section{BAB 3. METODE PELAKSANAAN}

Pelaksanaan kegiatan Pengabdian Kepada Masyarakat ini kami lakukan di Madrasah Aliyah Almisri, di desa Curahmalang, Kec-Rambupi, Jember. Mengingat sasaran dari kegiatan ini adalah siswa kelas 12 MA Almisri, maka pelaksanaan kegiatan dilakukan di Madrasah Aliyah Almisri. Yang menjadi pertimbangan mengapa tatap muka dengan siswa ini tetap dilaksanakan, terdapat beberapa alasan yang melatarbelakanginya. Yang pertama karena saat ini kita sudah memasuki era new normal dimana masa untuk memulai berinteraksi kembali dengan masyarakat, kemudian yang kedua karena dengan bertatap muka, hal-hal yang disampaikan apalagi terkait motivasi kepada siswa akan lebih mengena kepada siswa dan mereka akan lebih faham dengan apa yang kami sampaikan. Dengan mempertimbangkan beberapa alasan tersebut sehingga pihak sekolah mengizinkan kegiatan pengabdian kepada masyarakat dilaksanakan dengan bertatap muka langsung dengan para siswa kelas 12 di dalam kelas, 
asalkan tetap mematuhi protokol kesehatan yaitu menggunakan masker selama beriteraksi dan juga menjaga jarak antara satu dengan lainnya.

Para siswa kelas 12 MA Almisri sangat antusias pada kegiatan pengabdian kepada masyarakat ini, hal ini dapat terlihat dari respon positif dari para siswa diantaranya, beberapa diantara mereka menanyakan apakah dampak positif dan negatif kalo seseorang melanjutkan pendidikan ke banku kuliah, mereka juga amenanyakan apakah nanti kalo setelah kuliah ada jaminan akan mendapatkan pekerjaan, dan lain sebagainya. Selain itu respon positif dari siswa kelas $12 \mathrm{MA}$ Almisri yaitu ada beberapa siswa yang langsung meminta nomer telpon STIE Mandala karena mereka sangat tertarik untuk melanjutkan pendidikan ke bangku kuliah.

\section{BAB 4. HASIL DAN LUARAN YANG DICAPAI}

Adapun hasil dan luaran yang dicapai setelah pelaksanaan kegiatan pengabdian kepada masyarakat dengan judul "Motivasi Belajar Di Saat Pandemi Covid-19 Bagi Siswa Madrasah Aliyah Almisri, Di Desa Curah Malang, Kecamatan Rambipuji- Jember" adalah sebagai berikut:

1. Setelah adanya kegiatan pengabdian kepada masyarakat ini, siswa kelas 12 MA Almisri semakin termotivasi untuk menyelesaikan pendidikannya hingga lulus walaupun di tengah pandemi covid-19.

2. Dengan adanya kegiatan pengabdian kepada masyarakat ini, siswa kelas 12 MA Almisri semakin termotivasi untuk melanjutkan pendidikan ke bangku kuliah setelah mereka lulus nanti. Hal tersebut dapat dilihat dari respon mereka saat kegiatan pengabdian ini berlangsung. Mereka menanyakan beberapa hal terkait perguruan tinggi, kepastian mendepatkan pekerjaan apabila mereka kuliah, bahkan beberapa siswa laangsung meminta nomer telpon kampus STIE Mandala.

Respon positif dari siswa kelas 12 MA Almisri ini kami sampaikan langsung kepada pihak sekolah. Kemudian Kepala Sekolah juga menyarankan agar adanya kerjasama yang berkesinambungan antara pihak STIE Mandala dengan MA Almisri, agar kegiatan motivasi siswa dapat dilakukan secara rutin setiap tahun 
untuk memotivasi para siswa. Dengan harapan pada akhirnya para siswa lulusan MA Almisri dapat benar-benar melanjutkan pendidikan di bangku kuliah.

\section{BAB 5. RENCANA TAHAPAN BERIKUTNYA}

Berdasarkan feedback dari para siswa kelas 12 Madrasah Aliyah Almisri atas kegiatan pengabdian kepada masyarakat yang telah kami lakukan ini, membuat kami selaku dosen STIE Mandala termotivasi untuk menjadikan kegiatan ini sebagai kegiatan rutinitas yang dilakukan setiap tahun, mengingat sasarannya adalah siswa kelas 12 yang notabennya sangat perlu mendapatkan motivasi dari beberapa pihak, baik dari pihak internal sekolah maupun pihak eksternal sekolah. Motivasi ini dapat berupa motivasi belajar dengan memotivasi siswa agar menyelesaikan sekolahnya hingga lulus, dan juga motivasi kepada siswa agar melanjutkan studi ke jenjang yanag lebih tinggi yaitu kuliah di perguruan tinggi.

Dari kegiatan pengabdian kepada masyarakat yang kami lakukan ini, kami mendapatkan beberapa informasi, bahwasannya masih ada masyarakat desa Curahmalang yang putus sekolah pada jenjang pendidikan tingkat Sekolah Dasar (SD) / sederajat dan Sekolah Menengah Pertama (SMP) / sederajat. Mereka yang putus sekolah biasanya langsung bekerja di sawah mengikuti orang tuanya namun ada juga yang langsung menikah. Berdasarkan realita tersebut kami memiliki rencana tahapan selanjutnya yaitu memotivasi siswa SD / sederajat dan SMP / sederajat agar menyelesaikan sekolah hingga lulus. Hal ini kami lakukan karena kami merasa ikut bertanggung jawab dalam mensukseskan pendidikan nasional, sekaligus berpartisipasi mengentaskan kemiskinan dengan salah satunya melalui jalur pendidikan.

\section{BAB 6. PENUTUP}

\subsection{Kesimpulan}

Berdasarkan beberapa hal yang sudah dijelaskan pada bab-bab sebelumnya, maka dapat di tarik kesimpulan bahwa:

1. Siswa kelas 12 Madrasah Aliyah Almisri sangat termotivasi untuk menyelesaikan pendidikan di MA Almisri hingga lulus walaupun di tengah pandemi covid-19.. 
Jurnal Pengabdian Masyarakat, Vol.1 No.1, Februari 2021, hlm. 20-27

2. Siswa kelas 12 Madrasah aliyah Almisri termotivasi untuk melanjutkan pendidikan ke jenjang yang lebih tinggi yaitu melanjutkan ke bangku kuliah setelah lulus nanti.

\subsection{Saran}

Adapun saran yang dapat kami sampaikan diantaranya sebagai berikut:

1. Sebaiknya kegiatan pengabdian kepada masyarakat dengan sasaran siswa kelas 12 dilakukan secara rutin setiap tahun guna memotivasi belajar siswa hingga lulus, dan juga memotivasi untuk dapat melanjutkan pendidikan ke jenjang yang lebih tinggi yaitu kuliah di perguruan tinggi.

2. Mengingat masyarakat desa yang putus sekolah tidak hanya pada tingkat Sekolah Menengah Atas (SMA)/ sederajat, namun ada beberapa yang putus sekolah pada tingkat Sekolah Dasar (SD) ataupun Sekolah Menengah Pertama (SMP), sehingga sebaiknya kegiatan pengabdian kepada masyarakat juga dilakukan di tingkat pendidikan SD/sederajat maupun SMP/sederajat juga.

\section{DAFTAR PUSTAKA}

Nashar. (2004). Peranan Motivasi dan Kemampuan Awal dalam Kegiatan Pembelajaran. Jakarta: Delia Press.

Sadirman. (2004). Interaksi dan Motivasi Belajar. Jakarta: PT Rineka Cipta.

Slameto. (2003). Belajar dan Faktor-faktor yang Mempengaruhinya. Jakarta: PT Rineka Cipta.

https://m.facebook.com/kota.rambipuji/post/ 